\title{
Juridical Analysis of the Amount of Diyat Toward Armed Conflict Victims in Aceh
}

\author{
${ }^{1}$ Munawarsyah, ${ }^{1}$ Januddin, ${ }^{1}$ Muhammad Jafar \\ ${ }^{1}$ Lecturer at Shariah Science College of Ummul Ayman Pidie Jaya \\ tgkdrsaiful@gmail.com
}

\begin{abstract}
Islamic criminal law recognizes a kind of punishment called as diyat (compensation) for victims of murder and torture which has been apologized by the victim or family of victim. Diyat is amount of money or properties that should be paid by the perpetrator due to the death or damage of victim body. The legal basis for the determination of diyat can be found in Koran, chapter Al-Baqarah verse 178. Apart from that, there is Hadist of Muhammad Prophet written by Abu Dawud (peace be upon him), explaining the amount of diyat based on crime category whether murder or torture.

Aceh Governance has implemented this kind of punishment as a solution on criminal offences in realizing and fulfilling justice for armed conflict victims since 2002. In providing the policy of such payment for the victims in Aceh is based on the assumption that they are under the responsibility of state, therefore the government has determined the compensation on them. The amount of the compensation provided for the victims is not equal to the amount ruled by Islamic criminal law. Therefore, it is interesting to explore regarding the concept becoming the basic for determining it by Aceh Government, and compared it to the amount ruled by the law.

The research reveals that the sum of money for the compensation of what called diyat based on Islamic criminal law is the standard concept but it can be replaced by sum of money or properties that have equal price. The basic rules for this punishment in Islamic criminal law can be found in Al-Baqarah verse 178 of Koran. Moreover, regarding the sum of payment that should be provided can be found in Hadith of Prophet of Muhammad Peace be upon him which is told by Imam Abu Daud, mercy Allah for him. Practically, in Islamic criminal law the court, responsible persons and a due date for the payment must decide it. The rule consisting in the Islamic law is really different from the implementation of compensation done by Aceh Government towards the victims in Aceh.

It is recommended that the Aceh Government should realize the rules of the sum of compensation that should be received by the victims or the families based on the determination of the Court as a legal basis. In addition, the Central government as the main responsible party in repairing the condition of the society after the conflict should become the priority and absolute. The law enforcement in fulfilling the rights in Aceh should be done by involving some parties especially priest. Hence the society of the victims in Aceh obtains justice and legal certainty to get their rights.
\end{abstract}

Keywords: amount of diyat; Aceh Government 


\section{Introduction}

Diyat replaces soul or body, which is given as compensation by a perpetrator to the victim or his heirs for murder or a criminal offense of crimes against members of one's body (Mohd Din, 2009: 62). Islamic law deems diyat as principal punishment for crimes like murder and deliberate persecution or murder and persecution that occurred due to an error (Abdul QadirAudah, without year: 668). The base penalty diyat is al-quran and SunnahRasullullah SAW contained in the letter an-Nisa 'verse 92 which means, "... and whosoever kills a believer because the mark! (Let) it free a believing slave, and pay diyat submitted to his family (the slain), unless they (the family was killed) charity..." Based on, Rasullullah SAW hadith narrated by Abdullah bin Amr means,"... remember that diyat against murder and murder mark! Similar deliberately using whips and sticks are 100 camels, made up of 40 head pregnant". (HR. Abu Daud). Typically, diyat is divided into two, namely diyat heavy and light diyat. Levels of the heavy diyatdiyat to be paid by the perpetrators of deliberate murder by the number of 100 camels with Camel 30 Camel category 4 year old, 30 camels aged 5 years and 40 camels of leaders (Abdullah Bin Muhammad, 2004:381). Meanwhile lightly diyat is diyat to be paid by the offender intentionally murder jinayah than 100 camels in the form consists of 5 kinds: 20 female camels 3 years, 20 female camels 4 years, 20 female camels 2 years, 20 camels 2 years old male and 20 female camels 1 year. In other words, from the foregoing it is understood that the weight diyat only charged for intentional murder. While mild Diyat charged to criminal homicide because a similar fall into error and deliberate murder, persecution and crimes against limbs.

The Government of Aceh has provided Diyat as a solution to one form of crime to follow-up as well as justice for victims of the conflict in Aceh since 2002. Aceh government issued a policy in this regarding the form of recommendations to give Diyat (compensation) to victims or their families. This recommendation was issued on the basis of the assumption that the State takes responsibility for the welfare of its citizens, especially those who are victims of crimes during the conflict in Aceh who had never received the attention (DinasSyari'at Islam ProvinsiNanggroe Aceh Darussalam 2006: 69). It is an issue concerns the magnitude of diyat (compensation) given to the victims, because the amount of diyat amount specified in Islamic criminal law provisions are not comparable to the amount by which the amount determined by the Government of Aceh. Authors interested in doing research on juridical analysis of the concept of law are the source of the determination of the amount of funds by the Government of Aceh diyat.

\section{Literature Review}

Punishments or sanctions for the perpetrators are intended to regulate and maintain the security of public life, between the individual and the individual and the individual with society. In law enforcement or sanction known some criminal law theory that can be described as follows: 
1. Reward theory (absolute).

According to the theory, the basic penalty is known as the impact of the crime. Due to criminals has caused harm or suffering to others, offender is also subjected to suffering. Some legal experts who embrace this theory is Immanuel Kant, Hegel, Herbart, Stahl, Jean Jacques Rousseau (LedenMarpaung, 2005:105-107)

2. Aim Theory(relatieve), according to this theory is the punishment meted out to achieve the aims and objectives of the punishment, nyakni to fix gaps in the community as a result of which arise because of the crime. In addition the law also aims to prevent (prevention) crime (LedenMarpaung, 2005:105-107)

3. Combined Theory theory combined; basically gubungan theory is a combination of the two theories outlined above. Combination of both theories taught that sentencing offenders to each intended to maintain order in the community and improve the legal personal crimes. More breadth to maintain order and balance between an individual's lifestyle with another individual, the individual with the society in the state and nation (LedenMarpaung, 2005:105-107)

According to Islamic law, Punishment is a reward for the perpetrators of organized crime by Personality 'which are generally aimed at the welfare of the community. Detailed stipulation of penalties purpose is to keep the benefit of an individual, to protect the public from damage, stop the people of sinner and lead them to always obey Allah and His Messenger (Abdul QadirAudah, 1997:609). Basically the penalties prescribed in the Islamic Shari'a must fulfill certain criteria, which can be described as follows:

1. Penalties should be established to prevent the perpetrator to the crime after being convicted.

2. Punishment should be directed to the benefit of society, though the punishment is severe punishment or set a lighter sentence.

3. Penalties prescribed should be able to keep the perpetrator of the crime, if not possible then the perpetrators should be eliminated.

4. All types of punishment should be able to realize the benefit of individuals and society as a whole, and therefore the sentence cannot be engineered.

5. Sentence should contain a public education that is around and be a reward for the perpetrators (Abdul QadirAudah, 1997:610).

The comparison of the purpose of the application of Islamic criminal law penalties, both criminal law and equally positive are to keep the benefit of society as well as individuals. To realize the benefit of the application of the penalty or sanction is something effort to prevent crime, made repairs and a deterrent for offenders not to repeat it again.

Shari'ah law makes diyat as principal punishment for murder and persecution accidentally. As for the deliberate murder is diyat as a substitute punishment if received forgiveness (Qisashs) of the families of the victims. But the levels are not the same diyat, where the deliberate murder and persecution deliberately determined by weight diyat. As for the murder and persecution accidentally accidentally is diyat light. 
Pursuant to the implementation of diyat that have been implemented by the Government of Aceh from 2002 to 2008 which aims to reduce resentment and give more attention to the families and victims of the conflict. Another effort is to tackle crime in the community that have a preventive effect (wawancara. Abdullah Saleh 27 May 2013).

In legal system, the purpose of the penalty is applicable compensation, restetusi and rehabilitation for victims of crime in the form of compensation as well as the repair of any damage caused to the victim or his property. In its application for judicial enforcement of diyat in Aceh closer to the award of compensation in the form of compensation provided by the State should be the responsibility of the perpetrators of the crime itself. This arises not because of compensation to the victim but on the basis of the responsibility of the State towards the number of casualties during the conflict in Aceh, therefore, be civil compensation for victims of crime directly involved in the determination of government policy (the reposibleresociety).

\section{Research Method}

The object of the research is based on the issues that are examined by Juridical Analysis Settings of Diyat amount Against Conflict Victims in Aceh that is included discussion of both legislation and regulation Governor decree of Aceh Peace strengthening the Agency that contain provisions diyat amount in settlement of the conflict in Aceh.

Based on this type of study is a normative legal research or legal research dokrinal (Bambang Sunggono, 2012:41). The approach used in this study in the form of legislation (satute approach) is to examine all laws or regulations that are related to a legal case that is being addressed (Peter Mahmud Marzuki, 2008:93). This study also uses a conceptual approach (concep approach) refers to the views developed in the jurisprudence (Peter Mahmud Marzuki, 2008:93-95)whether in the Indonesian law or the Islamic one. The other problems are the implications of the adoption by the Government of Aceh diyat as well as the purpose of the diyat compensation for victims of the conflict in Aceh; therefore this type of research is an empirical study or research non-dokrina 1(Bambang Sunggono, 2012:41). Source of the data obtained in this study can be categorized into primary data and secondary data. This study uses empirical juridical normative and therefore data collection techniques used in this research is the research library (library research) and research field. Primary data are the ingredients that are auto ritatife means having authority, while secondary data is data in the form of publication of the law that does not include official documents (Ronny Hanitijo Soemitro, 1991:141)

The materials that I use are primary in this study is the Governor NAD Decree No. 330/106/2006 on the Establishment of the Aceh Reintegration Agency, the Aceh Governor Regulation No. 05, 2011 on the Organization and Administration of Organizational Aceh Reintegration Agency, Aceh Governor Regulation No. 02, 2013 On the Organizational Structure and Work Agency for Strengthening Peace in Aceh (BP2A), decision Aceh

Reintegration Board Number: 01/SK/BRA/IV/2006 regarding the Guidelines 
Development and Community Empowerment in the Context of Aceh Reintegration and regulations of other statutory and reading material that discusses it.

Secondary data sources were used in this study all the material which give the explanation of the primary data sources, including scientific works of jurists, seminar papers and various data explanation of terms used in this study such as legal dictionaries, encyclopedi as and so that associated with this research.

data obtained directly from the source through the interview consisted of a few respondents and informants is Head of Shari'a in Aceh Province, Chairman Baitul Mal Aceh, Aceh Governance Law Bureau Chief, Chairman of Commission A DPR Aceh, Peace Strengthening Public Relations Agency Aceh, Aceh Islamic Law Expert.

\section{Research Findings}

Determination of the magnitude of diyat can be obtained through a number of procedures that must be implemented in law enforcement.The purpose of punishment is to be achieved, particularly in the implementation of the diyat:

\section{Through Trial Process}

Proof of a crime is the first step to seek justice, and this is done through the judiciary $($ qadha'). According to the science of language, meaning qadha 'among others, completed, fulfilled and decided to make a provision of law or (LouitMa'luf, 1973: 68). Through the judicial process is gathered evidence that shows a person has committed a crime (murder and persecution both) intentionally or unintentionally. Proof of this is done to avoid the occurrence of errors in sentencing. Thus runs the court process is obligatory to seek justice. In addition, through the birth of a court process peace between the two sides and the peace it will also lead to the emergence of forgiveness between the warring parties. Therefore peace and forgiveness both parties also determines the magnitude of diyat.

2. Responsible Party for paying diyat

Normatively parties shall be responsible for payment of diyat it is itself criminal. This provision applies to deliberate homicide, where the treasure sipelakudiyat obligated itself when Qisas aborted. Similar to deliberate homicide and murder mark! Who must pay diyat not absolute perpetrator, family or heirs take responsibility, known as' aqilah (insurer diyat).

'Aqilah an exception to the general rules regarding sanctions (penalties) that fact must be borne by the offender himself. This exception is to ease the burden of my head due to the act of doing it by accident as well as a sign of affection between family members. On the other hand, this exclusion is done in order to maintain and ensure the rights of the family was killed, so that if one day the killer fled, the heirs of the slain still can claim their right to the killer's family. Similarly, if the perpetrator is poor and unable to pay diyat, it is reasonable assume that other family members to pay diyat the same to the affected families. 
As if the crimes did not have a family to protect or there but the devotee to bear diyat, then in this case, according to Imam Malik, Imam Shafi'i, Imam Ahmad ibnHanbal and Abu Hanifah said that Baitulmal take over position 'aqilah in diyat bear or bear part that cannot be covered by the 'aqilah (Said Hawa, 1993: 719)

3. Payment Limit of diyat

Regarding the murder diyat time distinguished by a murder committed by perpetrators jarimah.Diyat there are two ways that are paid with cash and matured during the three years. Diyat shall be paid in cash on the deliberate killing of a weighted diyat. While the tempo diyat (suspended for three years), this applies to the accidental killing of diyatdiyat light.

Such killing deliberately and fall into error, amounting to one third of diyat paid in each year for three years. There is also what distinguishes women with diyatdiyatmen, some men argue diyat paid out over three years, while the women diyat maturity for two years, the installment payment is one-third in the first year and then two-thirds in the second year.

As explained in the previous topic, diyat is intended as a form of punishment or a fine substitute for those who do the killing and persecution deliberately or to replace the losses suffered by the victim. Diyat punishment is also intended to minimize the occurrence of similar crimes in the future, in line with this diyat will also reduce feelings of resentment that exists within families because family members have been victims of a crime. This suggests that diyat is a form of punishment for people who commit murder and or persecution.

To analyze it in depth the experiences of the past that occurred in Aceh related to the ongoing conflict and cause many casualties; Government of Aceh provides a unilateral policy on society. In the case of Aceh, Aceh Government was responsible for the losses suffered by the people of Aceh that time. So we need to make a compensation policy, which subsequently termed diyat. Policies issued by the Government of Aceh should be able to get rid of resentment in the minds of the public (as well as compensation), so that people can live in peace in Aceh.

Diyat is compensation that is intended to be passed by the government for the crime of murder and torture committed by certain people in kepermerintahan duty. On this basis the Aceh government initiative to pay diyat, according to several provisions of the Government on this matter is:

1. Governor Decree No. NAD 330/106/2006 on establishment of the Aceh Reintegration Agency.

2. Aceh Governor Regulation No. 05, 2011 About Organizational Structure and Administration of the Aceh Reintegration Agency.

3. Aceh Governor Regulation No. 02, 2013 About Organizational Structure and Work Agency for Strengthening Peace in Aceh (BP2A)

4. Decree No. 01/SK/BRA/IV/2006 About Guidelines/instructions Technical Community Empowerment Program Aceh Reintegration Agency 
The Aceh Governor Decree No. 330/106/2006 regulates substantially the Governor cancellation decision No. 330/255/2005 on the Establishment of the Memorandum of Understanding Socialization Team Peace between the Government of Aceh with the Free Aceh Movement. In the second point contains about reshaping the Aceh Peace Reintegration Agency and some forums as supporting the Aceh peace program. At this point the decision further describes the specific tasks that must be implemented by the Executive Agency for Aceh Peace Reitegrasi and tasks to be carried out by the Supervisory body Aceh Reintegration, as well as some of the tasks of the forum with support peace in Aceh. Last provision describes the budget or costs associated with this decision imposed on the State Budget and Expenditure Budget Expenditure Aceh Province.

Pursuant to the Aceh Governor Regulation No. 05, 2011regulates the Organizational Structure and Administration of the Supervisory Board, the Executive Agency for Aceh Reintegration and organizational structure supporting the Aceh peace forum. Furthermore Acehnese Governor Regulation No. 02 of 2013, which regulates the organizational structure and functioning of the Agency for Aceh Peace Strengthening, set on the consideration that the Republic of Indonesia has committed to resolve the Aceh conflict thoroughly and continuously. Reintegration is intended to be implemented by the Government of Aceh. Apart froAceh Governor Regulation No. 02 of 2013 is also set on the consideration that the Governor of Aceh regulations No. 05 of 2011 should be revisited.

Considering the content,it is contained in a Decree/Regulation on the Governor aims to provide relief to the victims of the Aceh conflict as a step in an effort to accelerate completion konprehensif prolonged conflict in Aceh. In practice, reinforcements Aceh Peace Agency, previously known as the Aceh Reintegration Board issued a Decision About the concept of diyat aid for victims of the conflict in Aceh. This shows that as a government policy diyat Aceh has implemented legally or formally. In the Decree No. 01/SK/BRA/IV/2006 regarding the Guidelines/instructions Technical Community Empowerment Program Aceh Reintegration Agency, regulate comprehensively about how the methods that must be taken and the amount of diyat amount that will be distributed to victims of the conflict in Aceh.

Discussing about the massive amount of diyat issued in a matter of Rupiah, the Government of Aceh set sebasarRp. 60,000,000 for the soul, which allocated some Rp. $3,000,000$ in a single year. The most important thing that should be underlined here is the amount of provisions established diyat is not set forth in writing in Aceh Qanun. So the number of magnitude diyat provisions cannot be used as a basis for implementation. The fact that happened on the field, in fact since 2002 until 2007 diyat fund that channeled both the district level and the district does not mention the exact number of the casualties received by my family. Executing Agency for Aceh Peace Strengthening just explained that the number of funds and the implementation period will be adjusted to diyat Expenditure Budget Aceh (APBA). As for the victims of persecution akiban disability funding diyat different from diyat amount given to the dead or missing. The channeling of funds for victims of the conflict in Aceh diyat then submitted through the Aceh Provincial Social Service. 
Mechanism of the channeling of funds by the Government of Aceh diyat not pursued through the judicial process or stages in the judiciary. Determination of the number of scale diyat done without going through the court process can ignore the terms of major or minor crimes. So much tends to equalize the weight with a misdemeanor crime. Moreover without trial, to prove someone who will receive funds diyat not necessarily do. Therefore, the victim's family asked to fill out a form and submit some evidence as a condition of determination that such person or party as keluraga victim.

The periodization diyat funds, for the families who receive the first stage can no longer accept the second stage. Therefore in order to receive the next tranche of funds diyat, keluaraga victim should do the same pattern on the next stage. It means that the victim's family should melengkapai requirements specified as the first stage. This phenomenon is obviously very complicated because it should be the victims or their families who have received funding diyat the first stage can be considered eligible and can receive funds directly diyat next stage.

Families are eligible to receive funding diyat are children whether male or female, the wife or husband of the victim. If the victim does not have a son and a husband/wife then, are eligible to receive funding diyat are the parents and siblings of parents and siblings of the victim. For victims who have siblings more than one person diyat funds will be given to one of them after an agreement on who among those who will receive the funds diyat. If the victim has more than one wife, then diyat new funds will be given after an agreement on how the methods that should be done, as the funds have been divided into two or given to one of them and so on through a written statement about the deal. If the victim does not have a family or heirs then, diyat funds are not channeled, to avoid funding diyat to people who are not entitled to give birth to other problems in the future.

When we refer to the provisions of the Islamic penal code diyat funds awarded descent or lineage of the victim began the closest, if not then looks for another lineage onwards. If the victim really does not have a good lineage heir is on it like a father and mother or lineage thereunder as boys and girls or lineage who was beside him like a sibling, both men and women as well as the the victim did not have an heir of the bonds of marriage (husband/wife) then, diyat funds transferred to the treasury. This provision is based on the practice of the companions of the Prophet Muhammad Usman Bin Affan during (IbnKatsir, 2004: 347)

Provisions in the criminal law of Islam are proved to have a clear distinction in practice in the case of diyat funding for victims of the conflict in Aceh. The difference is in the provision of Islamic criminal law diyat uninterrupted disbursement caused by the absence of lineage heirs and the heirs of the victim for reasons of marriage. However, funds can be channeled to diyatBaitul Mal as the party entitled to receive the funds due to the relationship seagamadiyat.

View of Islamic law on the distribution of funds diyat in Aceh can be seen from several aspects: number of specified magnitude diyatjuridically, aspects of the mechanism and the stages to be followed in the disbursement of funds as well as aspects of periodization diyatdiyat funds for each of the victims, as well as aspects of the victim's 
heirs are entitled to receive the funds as compensation diyat. From the aspect of magnitude of diyat legally do not have the legal source of concrete so it does not guarantee the achievement of sentencing in Islamic law. From the aspect of the mechanism and the stages,it should be taken to go through the stages and in the judicial process from investigation through the process of judicial decision as covered in Islamic law. From the aspect of periodization diyat funds, in the case in Aceh takes a very long time that is up to 20 years to complete the diyat funds. While the Islamic criminal law, the maximum time that can be postponed is for 3 years. It means that funds can be done within a period of 3 years. Government of Aceh aspect heirs the right to limit only diyat funds for heirs who have lineage ties and marriage ties. Meanwhile, according to some scholars of Islamic jurisprudence stipulate that Baitul Mal including the party entitled to receive the funds due diyatseagama bond.

Based on the analysis of the determination of the magnitude of diyat writer who diperaktikkan by the Government of Aceh does not have a strong force of law and legal concepts concrete or clear legal source. Concretely diyat disbursement of funds by the Government to the victims of the conflict in Aceh was not in line with Islamic law. Because the Aceh government did not adopt the provisions implementing complex diyat set out in Islamic criminal categorization of types of cases ranging from up to sentencing for crimes or those responsible for the commission of a murde/ torture.

\section{Conclusions}

1. Amount of diyat provisions shall be determined in accordance with the provisions of law which we have detailed the criminal justice systems of Islam from various sources, in determining the amount of diyat not be left to the judge fully. In other words, the judge must decide the case based on the provisions of the texts. Islamic criminal law set up a procedure to be taken to resolve a case of murder or persecution, among others: (1) determination of diyat to go through the judicial process, (2) the parties who should be responsible, and (3) a specified period to pay diyat. The most fundamental thing in the resolution of cases diyat as a substitute punishment under Islamic criminal law is a must bedasarkan forgiveness and peace of the victim's family by involving judges as the authorities to establish penalties.

2. The conception that is used by the Government of Aceh in determining a solution diyatkonfilik settlement based on the prolonged Aceh Aceh Government policy to reduce conflict and eliminate resentment from the victim. The policy set forth in the Regulations of the Governor. While the conception of Aceh Government to determine the magnitude of diyat not based on any source of Islamic Criminal Law and other legal sources, therefore the determination of the Government of Aceh diyatbedasarkan unilateral assumption without involving the community and not on the basis of forgiveness from my family victims of the conflict. Determination of the amount of the diyat amount set forth in the technical manual Decision Aceh Reintegration Agency. Then, the implementation of Diyatfor victims of the conflict in Aceh is not within the 
framework of the implementation of Islamic law in Aceh. However, the intended diyat is a dedicated compensation for victims during the conflict in Aceh that was never settled in court.

\section{References}

Abdul Qadir Audah, 1997, At-tashri’ Al-Jinai’ Al-Islami.Jilid. 1. Dar Al katib Al-arabi. , tt, At-tashri' Al-Jinai' Al-Islami .Jilid. 2. Dar Al katib Al-arabi.

Bambang Sunggono, 2012, Metodologi Penelitian Hukum, Rajawali.

Dinas Syari'at Islam Provinsi Nanggroe Aceh Darussalam, 2006, Himpunan Undangundang, Cet, V.

Ibn Katsir, 2004, Al Bidayah Wan Nihayah, Darul Haq.

Leden Marpaung, 2005, Asas- Teori- Praktik. Hukum Pidana, Cet. KeII,Sinar Grafika.

Louit Ma'luf, 1973, Kamus al-Munjid, Darul Al-Masyriq.

Mohd Din, 2009, Stimulasi Pembangunan Hukum Pidana Nasional. Dari Aceh Untuk Indonesia. UNPAD PRESS.

Peter Mahmud Marzuki, 2008, Penelitian Hukum, Kencana.

Ronny Hanitijo Soemitro, 1990, Metode Penelitian Hukum dan Jurumetri, Ghalia Indonesia.

Said Hawa, 1993, Al- Islam, Daarus Salaam. 